\title{
The Genus Herposiphonia (Ceramiales, Rhodophyta) in the Coral Reefs Environmental Protection Area, Northeastern Brazil, with new records for Brazil and the Atlantic Ocean ${ }^{1}$
}

\author{
INGRID BALESTEROS SILVA ${ }^{2,4}$ and MUTUE TOYOTA FUJII ${ }^{3}$
}

(received: May 13, 2011; accepted: February 15, 2012)

\begin{abstract}
The Genus Herposiphonia (Ceramiales, Rhodophyta) in the Coral Reefs Environmental Protection Area, Northeastern Brazil, with new records for Brazil and the Atlantic Ocean). This paper presents a taxonomic study of taxa of the red algae genus Herposiphonia (Ceramiales) occurring on Maracajaú Reef in the Coral Reefs Environmental Protection Area (CREPA - Área de Proteção Ambiental dos Recifes de Corais) in Rio Grande do Norte State, along the northeastern coast of Brazil. The CREPA comprises coastline and continental shelf areas of the municipalities of Touros, Rio do Fogo, and Maxaranguape and includes sand dunes, coastal lagoons, and the adjacent shoreline and offshore reefs. Detailed morphological studies were made, considering recent taxonomic criteria for species delimitation of Herposiphonia, and five species were identified: $H$. delicatula, $H$. nuda, H. parca, $H$. secunda, and $H$. tenella, thus increasing the number of species in the genus from three to six. Herposiphonia delicatula and H. parca represent new occurrences for Brazil, and H. nuda is reported for the first time for the Atlantic Ocean.
\end{abstract}

Key words - Maracajaú Reef, macroalgae, morphology, Rio Grande do Norte, taxonomy

\section{INTRODUCTION}

The red algae genus Herposiphonia (Ceramiales, Rhodophyta) comprises about 56 species widely distributed throughout tropical and warm-temperate regions of the world (Masuda \& Kogame 2000). The genus is distinguished from other members of the tribe Herposiphoniae by the production of the first pericentral cell on the side opposite to the initial branch cell in the ventral portion of the thallus (Morrill 1976). Herposiphonia is characterized by having a dorsiventral habit, polysiphonous and uncorticated thalli, with a main prostrate axis from which simple determinate branches (rarely branched) as well as indeterminate branches (generally with the same branching pattern as the parental axis) are exogenously formed (usually in regular sequences); the apex of the young main axis is usually rolled upward and curved; vegetative trichoblasts and reproductive structures are formed exclusively on determinate branches (Hollenberg 1968, Masuda et al. 2006).

Species discrimination within the genus Herposiphonia is usually difficult (particularly with vegetative plants) due to features such as the numbers of segments, the numbers

1. Part of the $\mathrm{PhD}$ thesis of the first author, Programa de Pós-Graduação em Biodiversidade Vegetal e Meio Ambiente, Instituto de Botânica, SP, Brazil

2. Instituto de Botânica, Graduate Program, Av. Miguel Estéfano, 3687, 04301-902 São Paulo, SP, Brazil

3. Instituto de Botânica, Núcleo de Pesquisa em Ficologia, Av. Miguel Estéfano, 3687, 04301-902 São Paulo, SP, Brazil

4. Corresponding author: ingridbasilva@gmail.com of periaxial cells produced by each segment, branching patterns and the lengths of determinate branches, as these are variable in many species (Masuda $\&$ Shimada 2003). Other features, however, seem to be reliable for species diagnoses. Masuda \& Shimada (2002) summarized 25 taxonomic characters useful in distinguishing species within the genus, a number of which were indicated (Masuda \& Shimada 2003) as being especially important because they demonstrated no intraspecific variation: the development of distichous branching, the shape of determinate branches (terete, compressed or clavate), the development of branching in determinate branches, the presence/absence of conspicuously elongated suprabasal segments of determinate branches, the frequency and arrangement of the vegetative trichoblasts, the presence of one or two tetrasporangia per segment, the position of the tetrasporangium chain in the thalli (distal, middle, or proximal), the shapes, sizes, and positions of the cystocarps (terminal, distal, or proximal), thickened growth of cystocarp-bearing branches, as well as the development of the cystocarps and the positions (distal or proximal) and arrangements (spiral or secund) of the spermatangial branches.

Ten species of Herposiphonia have been reported for warm-temperate and tropical western Atlantic regions: $H$. arcuata Hollenberg, H. bipinnata M.Howe, H. delicatula Hollenberg, H. filifera Hollenberg, H. parca Setchell, H. pecten-veneris (Harvey) Falkenberg, H. secunda (C.Agardh) Ambronn, H. tenella (C.Agardh) Ambronn, H. xaymaca V.J. Champan, and H. variabilis Hollenberg (Wynne 2011). Another four species have been reported 
for the eastern Atlantic coast: $H$. didymosporangia Stegenga \& Kemperman, H. guineensis Lawson \& John, $H$. heringii (Harvey) Falkenberg, and H. paniculata Baardseth (Baardseth 1941, John et al. 2004). Only three species of Herposiphonia are currently known from Brazil: H. secunda (Joly 1965, Baptista 1977, CordeiroMarino 1978, Pinheiro-Joventino et al. 1998, Szèchy et al. 2004) and H. tenella (Joly 1965, Oliveira-Filho \& Ugadim 1974, Baptista 1977, Cordeiro-Marino 1978, Pereira et al. 2002, Villaça et al. 2006) are both widespread along the Brazilian coast, while H. bipinnata (Yoneshigue 1985, Nunes 2005) is less common. Considering the extent of the Brazilian coastline (more than $8,000 \mathrm{~km}$ ) (Tessler \& Goya 2005) and the fact that 10 species of Herposiphonia were reported in the updated checklist of Wynne (2011) for the tropical and subtropical western Atlantic region, the number of species occurring along the Brazilian coast may well be underestimated.

Recent studies of the marine flora on the Maracajaú Reef in the Coral Reefs Environmental Protection Area (CREPA) in northeastern Brazil have provided new information about the ecology and macroalgae assemblages found in that country (Silva 2006, 2011, Marinho-Soriano et al. 2008). The CREPA includes the coastline and continental shelf areas of three municipalities of state of Rio Grande do Norte (Touros, Rio do Fogo, Maxaranguape) and helps tech sand dune areas, coastal lagoons, and adjacent shoreline and offshore reefs. Those reefs have been impacted with degradation for decades, primarily due to overfishing and uncontrolled tourism, which is accompanied by motorboat traffic and anchoring (with the leakage of oils and fuels), and poorly organized coastal occupation (Amaral et al. 2005). Scuba diving as well as subsistence and sport fishing (which are locally important economic activities), however, have been regulated to control and reduce the numbers of visitors in the area (Amaral et al. 2005). In spite of their great importance to local inhabitants these areas have not been studied in detail and their flora is it best poorly known (Silva 2011).

During our survey of the Maracajaú Reef, three species of Herposiphonia that had never been reported in Brazilian waters were found growing as epiphytes on macroalgae on the shallow offshore and costal reefs.
Two species (H. delicatula and H. parca) are known for the Atlantic Ocean (Schneider \& Searles 1991; Littler \& Littler 2000), while the third ( $H$. nuda Hollenberg) was previously only known to occur in the Pacific and Indian Oceans (Hollenberg 1968; Silva et al. 1987; Abbott 1999). This paper describes and illustrates five species of Herposiphonia occurring in Maracajaú $(H$. delicatula, H. nuda, H. parca, H. secunda, and H. tenella) and discusses the usefulness of some diagnostic features for segregating species of this genus.

\section{Study area}

The Maracajaú reefs $\left(5^{\circ} 21^{\prime} 12^{\prime \prime}-5^{\circ} 25^{\prime} 30^{\prime \prime} \mathrm{S}\right.$ and $35^{\circ} 14^{\prime} 30^{\prime \prime}-35^{\circ} 17^{\prime} 12^{\prime \prime} \mathrm{W}$ ) are part of the Coral Reefs Environmental Protection Area (CREPA - Área de Proteção Ambiental dos Recifes de Corais) located in Rio Grande do Norte State along the northeastern coast of Brazil. The reefs consist of extensive offshore formations about $7 \mathrm{~km}$ from the shoreline as well as sandstone banks along the coast. A rhodolith bank is found in the southern portions of the offshore reef while beds of Halodule wrightii Asch. (Ascherson seagrass) occupy the western side. During low tide, these reefs generally lie at depths of 0.5 to $2.0 \mathrm{~m}$, reaching $3.0 \mathrm{~m}$ in some areas. Samples were taken from both the offshore (sample sites included coral heads, rhodolith beds, and seagrass beds areas) and coastal reefs of Maracajaú.

\section{MATERIAL AND METHODS}

The specimens collected were fixed in $4 \%$ formalin in seawater, and voucher specimens were later mounted in 30\% Karo Syrup on microscope slides and deposited in the Herbarium at the Instituto de Botânica of São Paulo State, Herbário Maria Eneyda P. Kauffman Fidalgo (SP, according to Index Herbariorum). Sections for microscopic examination were hand-cut using a razor blade, stained with $0.5 \%$ aqueous aniline blue solution, and acidified with 1 $\mathrm{N} \mathrm{HCl}$ (Tsuda \& Abbott 1985). The numbers of periaxial cells were determined in squash preparations as well as cut sections. Mounted slides were made with stained thalli or fragments. Microscopic measurements were made using a calibrated ocular micrometer. Photomicrographs were taken using a Sony W5 digital camera (Tokyo, Japan) coupled to a Primo Star Zeiss light microscope (Germany).

\section{RESULTS}

Dichotomous key to the 5 species of Herposiphonia considered in this study:

1. Axes producing determinate and indeterminate branches in regular sequences 2

1. Axes producing one or more segments between successive indeterminate branches, not in regular sequences Herposiphonia secunda 
2. Two to five trichoblasts or scar-cells per branch; branches $40 \mu \mathrm{m}$ or more in diameter, with 6 or more pericentral cells

2. Trichoblasts and scar-cells absent in vegetative plants; branches less than $40 \mu \mathrm{m}$ diameter, with up to 6 pericentral cells Herposiphonia nuda

3. Trichoblasts mostly well-developed, longer than the parent branch Herposiphonia parca

3. Trichoblast not as long as, never longer than, the parent branch 4

4. Thalli very delicate, pinkish; axes and branches thin, 70-90 $\mu \mathrm{m}$ and $40-50 \mu \mathrm{m}$ in diameter respectively; sexual reproductive structures formed on proximal segments of determinate branches Herposiphonia delicatula

4. Thalli coarse, brownish; axes and branches thick, 80-100 $\mu \mathrm{m}$ and 70-80 $\mu \mathrm{m}$ in diameter respectively; sexual reproductive structures formed on distal segments of determinate branches Herposiphonia tenella

Herposiphonia delicatula Hollenberg, Pacific Science 22: 540, 543. 1968.

Figures 1-5

Thalli consist of delicate filaments, pinkish to dark red, epiphytes on large algae, attached by unicellular rhizoids with or without digitate tips. Prostrate indeterminate axes are terete, $60-90 \mu \mathrm{m}$ diam., segments 1-3 diam. long. The axes bear either a determinate branch (d) or an indeterminate branch (i) on every segment in a regular sequence of three determinate branches followed by one indeterminate branch $(\mathrm{d} / \mathrm{d} / \mathrm{d} / \mathrm{i}$ pattern $)$. Determinate axes are simple, terete, 6-8 pericentral cells, 40-60 $\mu \mathrm{m}$ diam., 12-17 (24) segments 1-2 diam. long, to $1.7 \mathrm{~mm}$ long, apical cell inconspicuous. Vegetative trichoblasts pseudosubdichotomously branched up to three times, rudimentary, or some becoming welldeveloped up to $340 \mu \mathrm{m}$ long, 2-4 per axis, developing spirally on successive segments at the tips of determinate axes. Tetrasporangia are formed in rectilinear series of 3-8 in the lower and middle sections of the fertile branches. Procarps laterally disposed in the lower half of determinate axes. Mature cystocarps and spermatangia were not observed.

Material examined: BRAZIL. Rio GRANDE DO Norte: Maxaranguape, Maracajaú, offshore reefs, rhodoliths bank, 31-VIII-2008, IB Silva \& EOV Martins (SP401.272).

Distribution: Atlantic: North Carolina, Florida. Indian: Maldives, Seychelles, Phillipines, Vietnam. Pacific: Micronesia, French Polynesia, Hawaii (type locality: Falas Island, Truk group, Carolina Islands).

Plants commonly found attached to other alga, such as Gelidium coarctactum Kützing, Palisada perforata (Bory) K.W.Nam, and Dictyotales. Although some workers consider Herposiphonia delicatula very close to H. tenella (Hollenberg 1968; Schneider \& Searles 1991), the distinction between them was obvious in our specimens (table 1). Individuals of $H$. tenella were more robust, with axes larger in diameter and stouter, segments as long as broad or commonly broader than long. Our specimens of $H$. delicatula demonstrated close resemblance to our specimens of $H$. nuda, both being very slender and close in thallus height as well as axis diameter (table 1). The former differs from the latter, however, in having determinate axes somewhat larger in diameter, with larger numbers of pericentral cells per segment, but mainly by the presence of trichoblasts (which are absent in vegetative branches of $H$. nuda) and the point of origin of the sexual reproduction structures, as we noted in our collected material, and in accordance with the original description by Hollenberg (1968) (table 1).

This species had been reported for the Indo-Pacific region and for the Caribbean, but this represents the first report of Herposiphonia delicatula for Brazil.

Herposiphonia nuda Hollenberg, Pacific Science 22: 548-549. 1968.

Figures 6-9, 11

Plants are very delicate filaments, pinkish to pale red, epiphytes on larger macroalgae, attached to the host by frequent unicellular rhizoids with or without digitate tips. Prostrate axes are 65-100 $\mu \mathrm{m}$ diam. with segments 1-2.5 diam. long, each consisting of six to eight pericentral cells. Primary axes bear determinate and indeterminate branches on every segment in a regular sequence of three determinate branches followed by one indeterminate branch $(d / d / d / i$ pattern), following the same pattern of branching. Some indeterminate branches continue to grow in the same way as the parental branch and keep the same branching organization, while some remain as primordial branches. Determinate branches are simple and very slender, 30-40 $\mu \mathrm{m}$ diam., with 4-6 pericentral cells and are relatively long (to $2.2 \mathrm{~mm}$ ) and composed of 20-35 (48) segments 2-3 diam. long. Vegetative branches 
terminate in a conspicuous conical or rounded cell. Trichoblasts and scar-cells totally lacking on vegetative branches. Procarps laterally disposed, developing above the median point of the fertile determinate axes, about 20 segments away from the apex and some 12 segments from the base. Tetrasporophytes and male gametophytes were not observed.
Material examined: BRAZIL. Rio GRANDE DO NoRTE: Maxaranguape, Maracajaú, offshore reefs, on coral heads, 28-VIII-2008, IB Silva \& EOV Martins (SP401.273).

Distribution: Pacific: Hawaii, Marshall Islands, Maldives, Micronesia, Wake Atoll. Indian: Phillipines and Korea.

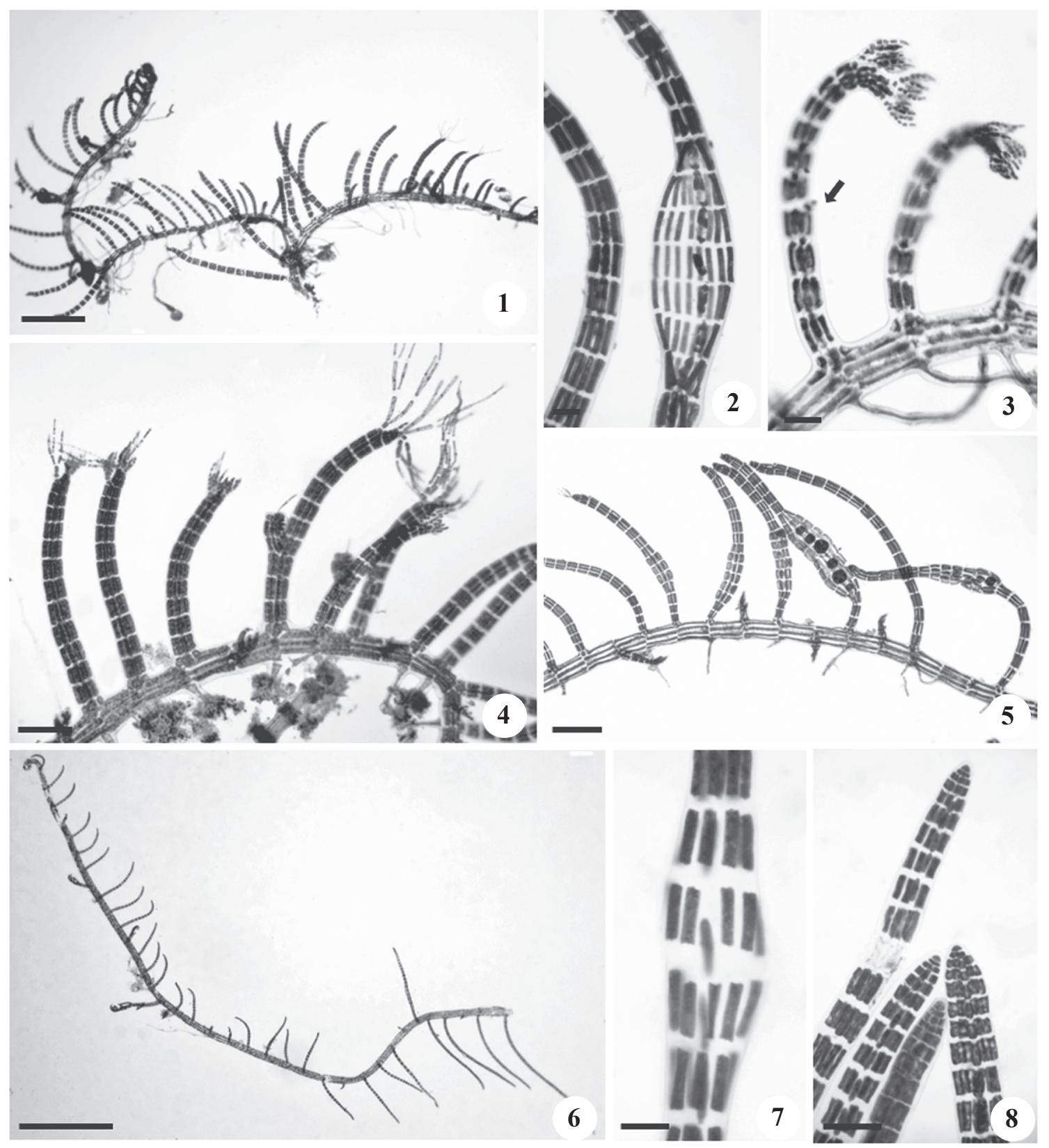

Figures 1-5. Herposiphonia delicatula. 1. Habit. 2. Squash preparation of a mature determinate branch showing eight pericentral cells. 3. Mature determinate with three spirally arranged trichoblasts. Note a sexual trichoblast initial in the middle portion of the branch (arrow). 4. Procarps in the lower portions of the fertile branches. 5. Tetrasporangial branches. Note tetrasporangia in the middle to lower portions of determinates. Figures 6-8. Herposiphonia nuda. 6. Habit. 7. Squash preparation of a mature determinate branch showing five pericentral cells and one cylindrical axial cell per segment. 8. Distal portion of determinates showing projected axial cells. Bar $=250 \mu \mathrm{m}(1) ; 50 \mu \mathrm{m}(2,3,8) ; 100 \mu \mathrm{m}(4,5) ; 1 \mathrm{~mm}(6) ; 30 \mu \mathrm{m}(7)$. 
To date, 14 species of Herposiphonia have been reported in warm-temperate and tropical Atlantic regions (Wynne 2011, Baardseth 1941, John et al. 2004). None of these species, however, possess mature determinate branches destitute of trichoblasts, or the relatively small numbers of pericentral cells in middle portion of determinate branches (4-6) as in H. nuda.

Specimens studied here were identified as Herposiphonia nuda, a species described from Hawaiian plants and distributed throughout Indo-Pacific regions; they had 4-6 pericentral cells, vegetative trichoblasts were totally absent, and procarpial trichoblasts originating at the distal portions of determinates - all features similar to those reported by Hollenberg (1968) and Abbott (1999), although the determinate axes in the present material were slightly more slender. $H$. nuda was described from Hawaii and can be easily recognized primarily by the very slender and long determinate axes composed of reduced numbers of pericentral cells per segment (only 4-5) and ending with a conspicuous rounded or conical apical cell, but principally by the mixture of all the characteristics cited above and the absence of trichoblasts and scar-cells (except for fertile male gametophytes) and the positions of origin of the sexual reproductive structures. Some specimens studied here had up to 6 pericentral cells, differing in this character from those described by Hollenberg (1968) and Abbott (1999) that had up to 5 pericentral cells. Whether this difference in the number of pericentral cells is significant enough to warrant establishing a new species for the Atlantic is doubtful, because all of the other characters match those of Pacific specimens (Hollenberg 1968).

Other species are known to lack vegetative trichoblasts: Herposiphonia clavata Wynne; H. prorepens (Harvey) Schmitz (which might be conspecific with $H$. akidoglossa Norris, according to Stengenga et al. [1997]); H. calva Millar, H. fissidentoides (Holmes) Okamura, and $H$. paniculata Baardseth (which might be conspecific with $H$. heringii (Harvey) Falkenberg, according to Stegenga et al. [1997]). However, these

Table 1. Morphological comparison of Herposiphonia species considered in this study (- = data not available).

\begin{tabular}{|c|c|c|c|c|c|}
\hline & H. delicatula & H. nuda & H. parca & H. secunda & H. tenella \\
\hline Diameter of main axes $(\mu \mathrm{m})$ & $60-90$ & $65-100$ & $90-150$ & $100-150$ & $120-150$ \\
\hline $\begin{array}{l}\text { Length of segments of indeterminate } \\
\text { axes (diam. long) }\end{array}$ & $1-3$ & $1-2.5$ & $1-1.5$ & $0.8-1.5$ & $0.8-1.3$ \\
\hline $\begin{array}{l}\text { Number of periaxial cells per segment } \\
\text { in main axes }\end{array}$ & $7-8$ & $6-8$ & $8-10$ & $7-9$ & $7-9$ \\
\hline $\begin{array}{l}\text { Diameter of determinate branches } \\
(\mu \mathrm{m})\end{array}$ & $40-60$ & $30-40$ & $55-70$ & $70-75$ & $70-80$ \\
\hline $\begin{array}{l}\text { Length of segments of determinate } \\
\text { branches (diam. long) }\end{array}$ & $1-2$ & $2-3$ & $0.8-1.3$ & $0.8-1.0$ & $0.8-1.0$ \\
\hline Length of determinate branches (mm) & 1.7 & Up to 2.2 & 1.5 & 1 & 1 \\
\hline Numbers of segments of branches & $12-17(24)$ & $20-35(48)$ & $12-16$ & $6-13$ & $8-13$ \\
\hline $\begin{array}{l}\text { Numbers of periaxial cells per } \\
\text { segment in determinate branches }\end{array}$ & $6-8$ & $4-6$ & $8-9$ & $7-8$ & $7-8$ \\
\hline $\begin{array}{l}\text { Trichoblasts and scar-cells on } \\
\text { vegetative branches }\end{array}$ & $\begin{array}{l}\text { Spirally, } 2-4 \text { per } \\
\text { axis, } 340 \mu \mathrm{m} \text { long, } \\
\text { branched up to } \\
\text { three times }\end{array}$ & $\begin{array}{l}\text { Totally } \\
\text { lacking }\end{array}$ & $\begin{array}{l}\text { Spirally, } 2-4 \text { per } \\
\text { axis, } 350-400 \\
\text { (1000) } \mu \mathrm{m} \text { long, } \\
\text { branched up to } \\
\text { six times }\end{array}$ & $\begin{array}{l}\text { Terminally, } \\
\text { 1-3 per axis, } \\
\text { branched } 2-4 \\
\text { times }\end{array}$ & $\begin{array}{l}\text { Spirally, } 1-3 \text { per } \\
\text { axis, branched } \\
2-4 \text { times }\end{array}$ \\
\hline $\begin{array}{l}\text { Position and arrangement of } \\
\text { tetrasporangia on parental branches }\end{array}$ & $\begin{array}{l}\text { rectilinear 3-8 } \\
\text { lower and } \\
\text { middle parts }\end{array}$ & - & - & - & $\begin{array}{c}\text { middle or } \\
\text { upper segments, } \\
\text { straight series } \\
\text { of } 3-8, \\
60 \mu \mathrm{m} \text { diam. }\end{array}$ \\
\hline $\begin{array}{l}\text { Position of procarps on parental } \\
\text { branches }\end{array}$ & $\begin{array}{l}\text { Lower half } \\
\text { portion }\end{array}$ & $\begin{array}{l}\text { Above the } \\
\text { median point }\end{array}$ & - & - & - \\
\hline
\end{tabular}


species differ from $H$. nuda by having higher numbers of pericentral cells in the middle positions of determinate branches, with 10 pericentral cells or more per each axial cell, while $H$. nuda has 4-5 (6) pericentral cells. Furthermore, $H$. prorepens and $H$. fissidentoides have compressed determinate branches that are arranged in a single row on the dorsal side of the primary axes in the former while laterally displaced to the left and to the right in the latter (Masuda et al. 2006). In addition to the higher numbers of pericentral cells in these species, $H$. paniculata and $H$. calva have proximally located cystocarps (Masuda \& Shimada 2003). H. falcata (Kützing) De Toni is another species rarely known to have vegetative trichoblasts, but it differs consistently from $H$. nuda by the presence of 10-14 pericentral cells per segment and by having basally located procarpial trichoblast (Stegenga et al. 1997).

The positions of the procarps in our material are in agreement with those cited by Hollenberg (1968): above the median point of the fertile axis. Hollenberg's (1968) description did not, however, mention the numbers of segments from the base (or from the apex) in which the procarps were found. Abbott (1999) reported procarps located at about the middle of the determinate axes in this species (table 1). Our specimens showed procarps developing 12 segments from the base and about 20 segments from the apex; but while there are more segments above the procarps than below them, the segments above the procarps are very short (0.3-1 diam. long), so that the procarps located in the upper third of the fertile branch and nearer the apex than the base. This species had been reported in the Indo-Pacific region and Pacific Ocean but had not been yet observed or reported for the Atlantic Ocean.

Herposiphonia parca Setchell, Univ. Calif. Publ. Bot. 12: 103. 1926.

Figures 10, 12-13, 16

Plants consist of delicate thalli growing as epiphytes on Palisada flagellifera K.M.Nam, attached by unicellular rhizoids. The axes are terete, having a branching pattern of three determinate axes followed by one indeterminate lateral (d/d/d/i pattern). Prostrate axes 90-150 $\mu \mathrm{m}$ diam., $8-10$ pericentral cells, segments 1-1.5 diam. long. Erect determinate axes up to $1.5 \mathrm{~mm}$ in height, with 12-16 segments 0.8-1.3 diam. long. Axes $55-70 \mu \mathrm{m}$ diam. basally, becoming gradually slender near the truncate tips, 45-50 $\mu \mathrm{m}$ diam., 8-9 pericentral cells, apical cell inconspicuous. Young determinate axes strongly curved upward, becoming straight when mature. Vegetative trichoblasts develop spirally at the tips of determinate axes in successive segments, 2-4 per axis. Trichoblasts commonly welldeveloped, 350-400 $(1,000) \mu \mathrm{m}$ long, with a relatively long basal cell $(20 \mu \mathrm{m}$ long $\mathrm{x} 30-35 \mu \mathrm{m}$ diam.), branched up to 5 orders, the cells becoming longer and thinner, or rudimentary, about $10 \mu \mathrm{m}$ diam. and 100-150 (180) $\mu \mathrm{m}$ long., branched up to 3 orders, with a small (to $10 \mu \mathrm{m}$ diam.) rounded basal cell. Rudimentary trichoblasts, as well more developed ones, observed growing on the same branch, with the smaller ones positioned towards the apex. Fertile plants were not observed.

Examined material: BRAZIL. Rio Grande Do Norte: Maxaranguape, Maracajaú, Ponta dos Anéis, intertidal coastal reef, on Palisada perforata, 25-II-2008, IB Silva \& EOV Martins (SP401.271).

Distribution: Atlantic: France, Florida, Cuba, Belize. Indian: Kenya, Tanzania, Maldives, Reunion Islands, Seychelles and India. Pacific: Japan, Micronesia, Hawaii.

Herposiphonia parca, as identified in the present study, is in conformity with the description presented by Hollenberg (1968) for Pacific specimens, Littler \& Littler (2000) for Caribbean material, and Dawes \& Mathieson (2007) for specimens from Florida. Abbott (1999) and N'eurt \& Payri (2010) found specimens with stouter erect axes in French Polynesia.

This species closely resembles Herposiphonia elongata Masuda \& Kogame (2000), as the branching patterns and the dimensions of the thalli of both species overlap. $H$. elongata produces up to four vegetative trichoblasts per branch in a spiraled sequence that can be very long and with dichotomies, as in H. parca; the female and male sexual structures are also terminal in both entities. Differences between these two species are seen only in the fertile tetrasporophytes and female gametophytes when the cystocarp is mature. The tetrasporangia in $H$. parca are located on the middle and lower segments in straight series (Hollenberg 1968, Abbott 1999) whereas those of $H$. elongata are on the middle and distal portions, frequently spiraled (Masuda \& Kogame 2000). Cystocarp-bearing branches of $H$. elongata become thickened as the cystocarp develops (Masuda \& Kogame 2000); this was not observed in $H$. parca (Masuda et al. 2006).

This species has been reported for the Indo-Pacific region, Pacific islands, and for the Caribbean - this being the first report of Herposiphonia parca for Brazil. 


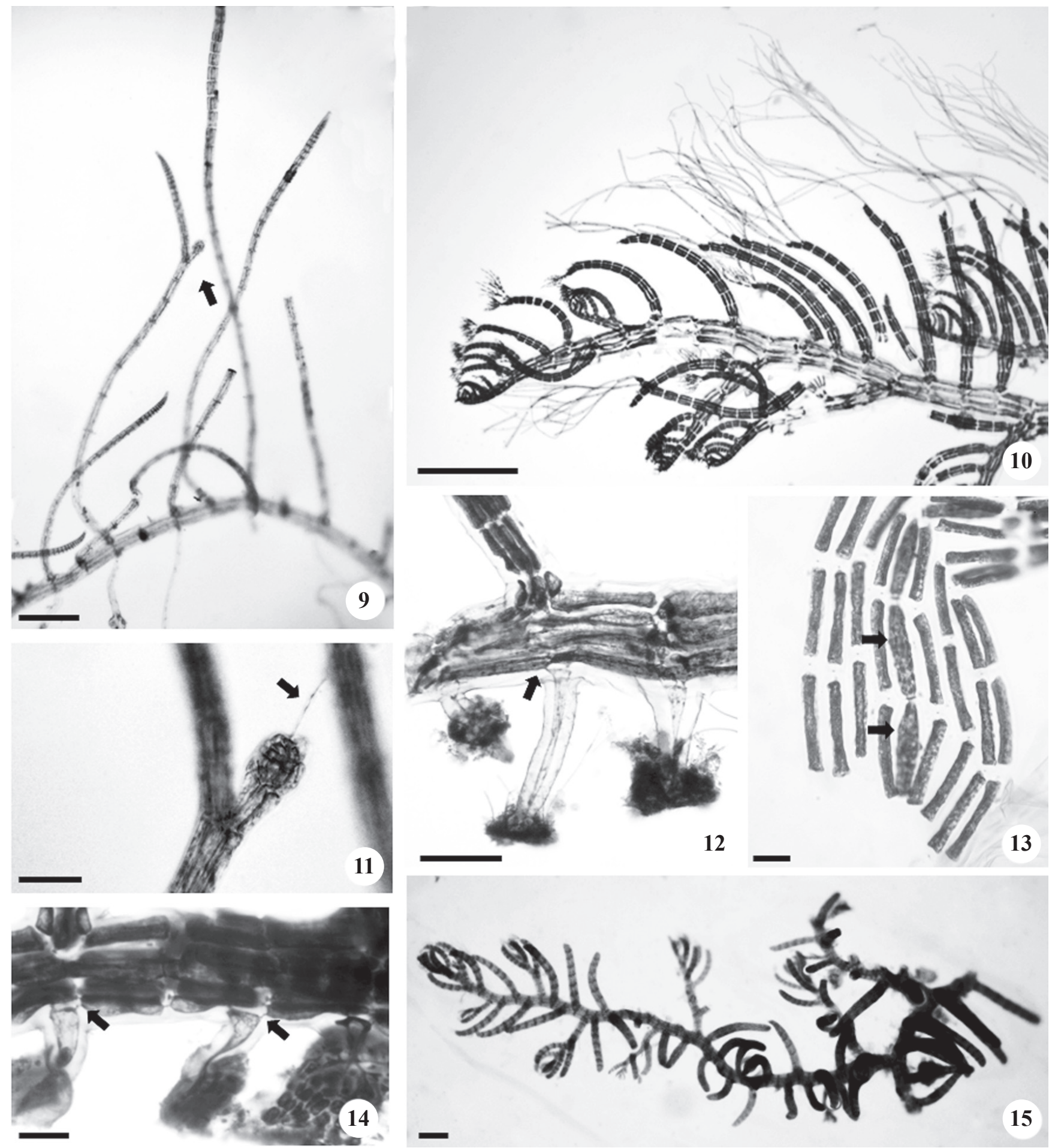

Figure 9. Herposiphonia nuda. Procarp (arrow) on the lower portion of a fertile branch. Figure 10. Herposiphonia parca. Apical portion of a prostrate axis with determinates bearing well-developed trichoblasts. Figure 11. Herposiphonia nuda. Procarp: arrow indicates a procarpial trichoblast. 12-13. Herposiphonia parca. 12. Proximal rhizoid with a digitate attachment pad. Note a secondary pit-connection between the closest periaxial cell of the segment and the distal side (arrow). 13. Squash preparation of a mature determinate branch showing eight periaxial cells and a thicker axial cell (arrows). 14-15. H. tenella. 14. Proximal rhizoids with a secondary pit-connection between the closest periaxial cell of the segment and the distal side (arrow). 15. Habit. Bar $=200 \mu \mathrm{m}$ (9); $500 \mu \mathrm{m}(10) ; 50 \mu \mathrm{m}(11) ; 100 \mu \mathrm{m}(12,13) ; 30 \mu \mathrm{m}(14) ; 1 \mathrm{~mm}(15)$. 
Herposiphonia secunda (C.Agardh) Ambronn, Bot. Zeitung 38: 197. 1880. झHutchinsia secunda C.Agardh, Syst. Alg.: 149. 1824.

Figures 20-21

Plants coarse and brownish red. Thalli terete, prostate axes 100-150 $\mu \mathrm{m}$ diam., segments 0.8-1.5 diam. long., 7-9 pericentral cells. Branching consist of one determinate branch between indeterminate branches or bare nodes. Erect determinate axes up to $1 \mathrm{~mm}$ height, 6-13 segments, 70-75 $\mu \mathrm{m}$ diam., segments 0.8-1.0 diam. long, 7-8 pericentral cells; apex blunt, apical cell inconspicuous. Vegetative trichoblasts terminal, rudimentary, 1-3 at the tips of determinate axes, pseudodichotomously divided 2-4 times. Fertile plants were not observed.

Examined material: BRAZIL. Rio GRANDE DO NoRTE: Maxaranguape, Maracajaú, offshore reef, flat reef zone, or coral heads on Dictyopteris delicatula J.V.Lamouroux, 27-II-2008, IB Silva \& EOV Martins (SP401.274).

Distribution: USA, Belize, Costa Rica, El Salvador, Panama, Caribbean, Venezuela, Brazil. Elsewhere, widespread in tropical and subtropical seas.

Herposiphonia secunda, identified in the present study, is in conformity with descriptions by Hollenberg (1968), Oliveira-Filho (1969), Schneider \& Searles (1997). The specimens had a close resemblance with others identified as $H$. tenella, having the same color, texture, diameter, segment lengths, and sometimes the same branching patterns (table 1). Differences from those species were only seen among plants bearing trichoblasts: in $H$. secunda the trichoblasts are terminal (figure 21) and in $H$. tenella they are spirally arranged in successive segments (figures 19, 20).

Herposiphonia tenella Ambronn, Bot. Zeitung Berlin 38: 161-174, 177-185, 193-200, 209-216, 225-233. 1880. 三 Hutchinsia tenella C.Agardh, Species algarum 2: 105. 1828.

Figures 14-15, 17-19

Plants coarse and brownish red. Thalli terete, having a branching pattern of three determinate axes followed by one lateral indeterminate $(\mathrm{d} / \mathrm{d} / \mathrm{d} / \mathrm{i}$ pattern). Prostate axes 120-150 $\mu \mathrm{m}$ diam., segments 0.8-1.3 diam. long., 7-9 pericentral cells. Erect determinate axes up to $1 \mathrm{~mm}$ in height, $70-80 \mu \mathrm{m}$ diam., $8-13$ segments with 0.8 1.0 diam. long, 7-8 pericentral cells. Apex blunt with an inconspicuous apical cell. Vegetative trichoblasts rudimentary, 1-3 at the tips of determinate axes in successive segments, pseudodichotomously divided 24 times. Tetrasporangia in the middle or upper segments of determinate branches in straight series of 3-8; mature tetrasporangia up to $60 \mu \mathrm{m}$ diam. Fertile gametophytes were not observed.

Examined material: BRAZIL. Rio GRANDE DO NoRTE: Maxaranguape, Maracajaú, offshore reef, flat reef zone, on coral heads, 27-II-2008, IB Silva \& EOV Martins (SP401.275).

Distribution: USA, Mexico, Caribbean, Brazil. Elsewhere, widespread in tropical to warm temperate seas.

Herposiphonia tenella, identified in the present study, is in conformity with specimens described by Hollenberg (1968), Oliveira-Filho (1969), and Masuda \& Kogame (2000), but also showed a high morphological similarity to $H$. secunda (table 1 ). The taxonomic relationships between these species are controversial (Morrill 1976). Some authors consider H. tenella as a form of H. secunda (Wynne 1985, 1998, Silva et al. 1987). Hollenberg (1968) regarded $H$. secunda as a form of H. tenella, although Hutchinsia secunda (C.Agardh 1824) has priority over Hutchinsia tenella (C.Agardh 1828), as argued by Wynne (1985) in making his new combination of Herposiphonia secunda f. tenella. However, the recognition of $H$. tenella and $H$. secunda as independent species is becoming common among authors (Oliveira-Filho 1969, Morrill 1976, Schneider \& Searles 1997, Masuda \& Kogame 2000) and there is strong evidence to support this point of view. Børgesen (1920), studying specimens of $H$. tenella and $H$. secunda from the Caribbean region ("West Indies"), at first thought they were individuals of the same species, but when male gametophytes were encountered differences in the positions and sizes of the spermatangial bodies were noted and they were described as distinct species. Morrill (1976) and Masuda \& Kogame (2000) also found differences in the positions and arrangements of the trichoblasts and spermatangial bodies: spermatangial branches and trichoblasts in spiraled in H. tenella and the fertile portion of spermatangial bodies have 10-12 segments, whereas the spermatangial branches and trichoblasts are terminally disposed in $H$. secunda, and the fertile portions of the spermantangial bodies have 4-5 segments (Børgesen 1920, Morril 1976, Schneider \& Searles 1997, Masuda \& Kogame 2000, N'Yeurt \& Payri 2010).

\section{DISCUSSION}

The genus Herposiphonia is widely distributed from tropical and warm-temperate waters (Masuda \& Kogame 2000) to sub-polar marine environments 

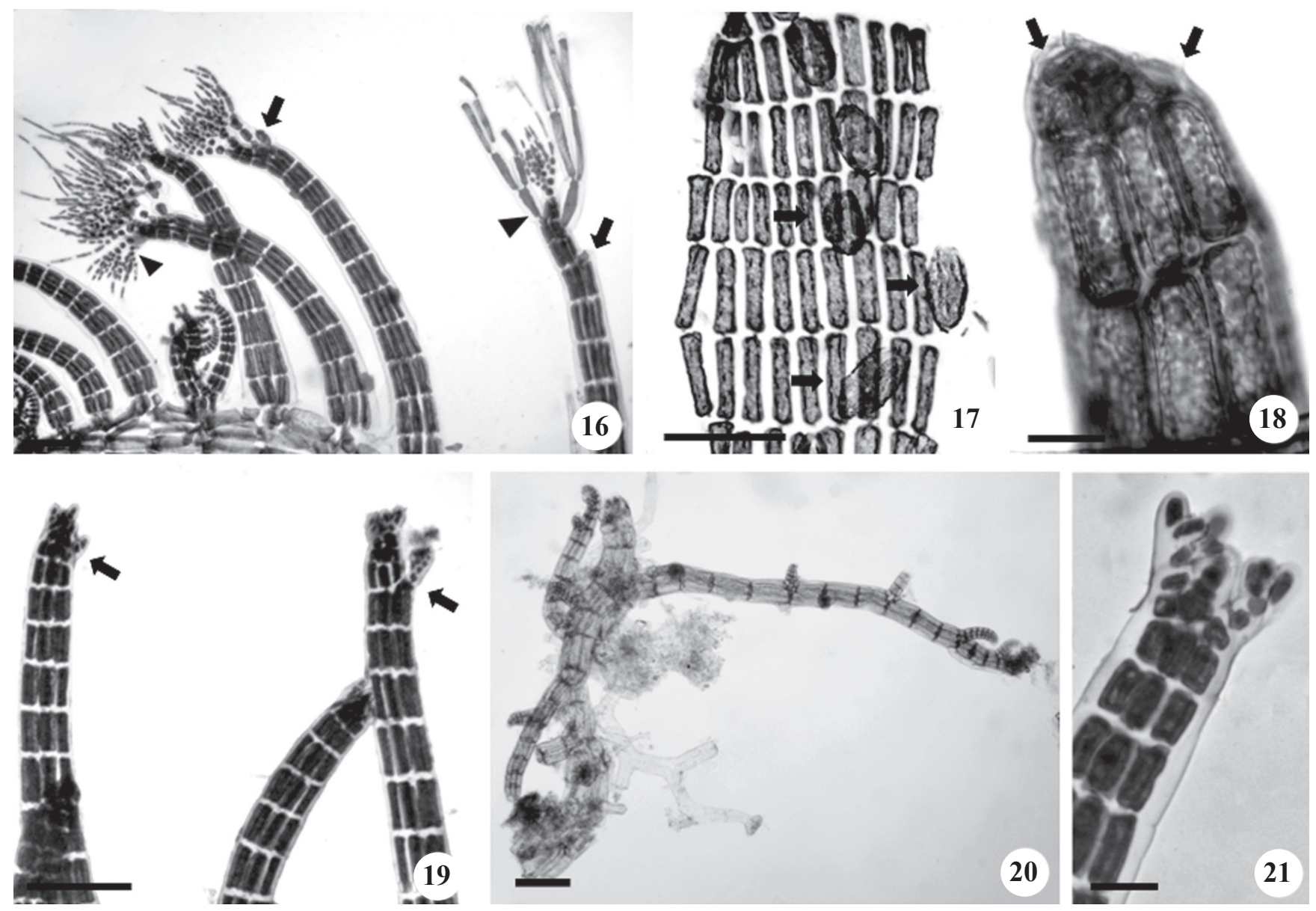

Figure 16. Herposiphonia parca. Apical portions of determinates showing trichoblasts (arrowheads) and scar-cells (arrow) spirally arranged on successive segments. 17-19. H. tenella. 17. Squash preparation of a mature determinate branch showing nine cylindrical pericentral cells and one cask-shaped axial cell (arrow) per segment. 18. Apex of a mature determinate branch showing scar-cells on successive segments. 19. Apices of determinate branches. Note the spiral arrangement of the trichoblasts on successive segments (arrow). 20-21. H. secunda. 20. Habit. 21. Apex of a determinate branch showing three terminal trichoblasts $(20 \mu \mathrm{m}) . \mathrm{Bar}=100 \mu \mathrm{m}(16,17,19) ; 20 \mu \mathrm{m}(18,21) ; 2 \mathrm{~mm}(20)$.

(Scagel et al. 1989, Papenfuss 1941) and in the majority of cases species identifications are not easily made. The difficulties encountered in making species diagnoses in this genus lie in the inconsistencies of the traditionally used vegetative characters, such as branching patterns, numbers of pericentral cells, and numbers of segments - all of which show minor variations in some species (Hollenberg 1968). Some vegetative features, however, show no variability and are considered useful: the shapes of the determinate branches (terete, compressed, or ligulate), the 3-D dispositions of determinate branches on the primary axis (the angle between the left and right determinate axes), the presence/absence of branching in determinate branches, the numbers of pericentral cells in the basal segments, the relative lengths of the suprabasal segments of determinate branches (i.e. if they are conspicuously elongated or not), the shapes of mature central axial cells and their sizes in relation to the surrounding pericentral cells, and the frequencies of vegetative trichoblasts (which are always deciduous in Herposiphonia and leave scar cells) (Masuda \& Shimada 2003). In many cases, however, these characters are not sufficient to identify a species - and combinations of vegetative and sexual features are required.

Hollenberg (1968) considered the frequencies of vegetative trichoblasts to be an important taxonomic feature, but the structures must be evaluated with some caution as they are always deciduous in this genus and can be confused with reproductive trichoblasts (Masuda et al. 2006). Herposiphonia nuda is one of the rare species in the genus devoid of vegetative trichoblasts, and it was identified on the basis of combinations of vegetative characters - such as the branching pattern, dimensions of the axes and segments, and principally 
by the combination of a reduced number of pericentral cells and the lack of vegetative trichoblasts or scar cells. A female individual with procarps positioned at the distal portion of the fertile branches was later found, thus supporting our identification. $H$. nuda is frequent in the area, occurring as an epiphyte on larger macroalgae such as species of Laurencia J.V.Lamouroux, Gelidium J.V.Lamouroux, and Dictyotaceae, commonly found in the flat zone of the reef during the dry and rainy seasons (when the procarpial plant was found).

Herposiphonia parca was also identified on the basis of vegetative specimens. The specimens examined here matched the original description of Setchell (1926) and those described by Hollenberg (1968) and Abbott (1999). In the absence of fertile material, we considered the specimens to represent $H$. parca because it is a species already recognized for the Caribbean region (Littler \& Littler 1997), which has a flora greatly resembling the tropical Brazilian flora; H. elongata, on the other hand, is thought to occur in tropical regions in the North Pacific (Malaysia, Masuda \& Kogame 2000; Japan, Masuda et al. 2006). This species is rare in the area, specimens were found attached to Palisada perforata growing in the intertidal zone on sandstone banks in the dry season.

Herposiphonia delicatula was described on the basis of Indo-Pacific material, and is widely distributed throughout that region (Hollenberg 1968, Abbott 1999) and in the tropical Atlantic (Morrill 1976, Schneider $\&$ Searles 1991). Populations around the world show extremely slender primary axes, the same numbers of pericentral cells (on indeterminate and determinate axes) and three or four vegetative trichoblasts. However, some morphological features are inconsistent among IndoPacific and Atlantic populations, such as the positions of tetrasporangia and procarpial trichoblasts, otherwise thought to be a valuable character in species segregation (Masuda \& Shimada 2003). Hollenberg (1968) described $H$. delicatula as producing procarpial trichoblasts in the lower portion of fertile branches, as in the studied material. Morrill (1976), on the other hand, reported that procarpial trichoblasts were initiated at the apex is of plants from North Carolina, but as the cystocarp matures the apex of the parental branch continues to grow and cystocarps can be found half way down the determinate branch. Indo-Pacific plants also have tetrasporangia in the proximal to middle portions of fertile branches (Hollenberg 1968) while those from the Atlantic Ocean (Schneider \& Searles 1991) are located in various positions on the fertile branch. The plants studied here had tetrasporangia located at the proximal to middle portions of the branches. Another difference was seen in the sterile tips of the spermatangial trichoblasts found in Atlantic specimens (Schneider \& Searles 1991). Hollenberg (1968, p.540) stated in his description "spermatangial stichidia lanceolate without a sterile tip." but the accompanying figure shows a sterile tip with 3 segments (Hollenberg 1968, p.541, fig. 1B). The position of the reproductive structure is the most important taxonomic criteria for species discrimination in Herposiphonia (Morrill 1976, Masuda \& Kogame 2000, Masuda \& Shimada 2002, 2003, Masuda et al. 2006), and the differences observed among global populations of $H$. delicatula are seriously discrepant, indicating that further studies will be needed to define the taxonomic relationship between Indo-Pacific and Atlantic specimens (Masuda \& Shimada 2003).

For many years the genus Herposiphonia was represented in Brazil by only three species: H. bipinnata, $H$. secunda, and $H$. tenella. In the present paper, specimens were accurately described considering all of the features discussed above, and five species were recognized in the local flora, adding three new records for Brazil; two of them ( $H$. delicatula and $H$. parca) were new occurrences for South Atlantic and one, $H$. $n u d a$, for the Atlantic as a whole, thus expanding their known geographical regions.

This report is a contribution to efforts to survey the infralittoral benthic seaweed flora of Rio Grande do Norte State which have largely been based on intertidal sampling. The discovery of the two new species of Herposiphonia for South Atlantic and one for the Atlantic ocean suggests that other taxa belonging to brown, green, and red seaweeds will be found and significantly increase the list of species known for this part of the world.

Acknowledgements - The present study was supported by the Conselho Nacional de Desenvolvimento Científico e Tecnológico (CNPq) and the Coordenação de Aperfeiçoamento de Pessoal de Nível Superior (Capes). I.B.Silva thanks Capes for the Ph.D. Fellowship, and M.T.Fujii thanks CNPq for the Research Productivity Fellowship (Proc. 301438/2009-9). Beneficiary of the financial support from Capes - Brazil.

\section{REFERENCES}

Abbott IA. 1999. Marine red algae of the Hawaiian Islands. Bishop Museum Press, Honolulu.

Amaral RF, Feitoza BM, Attayde JL, Batista DS, Mendes LF, Silva IB, Marinho-Soriano E. 2005. Diagnóstico ambiental preliminar da área de uso turístico intensivo (AUTI) no Parracho de Maracajaú. Instituto de Desenvolvimento Sustentável e Meio Ambiente do Rio Grande do Norte - IDEMA (Relatório interno), Natal. 
Baardseth E. 1941. The marine algae of Tristan da Cunha. Results of the Norwegian Scientific Expedition Tristan Da Cunha 1937-1938 9:1-173.

Baptista LRM. 1977. Flora ilustrada do Rio Grande do Sul. Boletim do Instituto de Biociências da Universidade Federal do Rio Grande do Sul 37:1-248.

Børgesen F. 1920. The marine algae of the Danish West Indies. v.2, Rhodophyceae, Part 6. Dansk Botanisk Arkiv 3:369-504.

Cordeiro-Marino M. 1978. Rodofíceas bentônicas marinhas do Estado de Santa Catarina. Rickia 7:1-243.

Dawes CJ, Mathieson AC. 2008. The seaweeds of Florida. University Press of Florida, Florida.

Hollenberg CJ. 1968. An account of the species of the red alga Herposiphonia occurring in the central and western Tropical Pacific Ocean. Pacific Science 22: 536-559.

John DM, Prud'homme Van Reine WF, Lawson GW, Kostermans TB, Price JH. 2004. A taxonomic and geographical catalogue of the seaweeds of the western coast of Africa and adjacent island. Beheifte zur Nova Hedwigia 127:1-339.

Joly AB. 1965. Flora marinha do litoral norte do Estado de São Paulo e regiões circunvizinhas. Boletim da Faculdade de Filosofia, Ciências e Letras da Universidade de São Paulo, série Botânica 21:1-393.

Littler DS, Littler MM. 1997. An illustrated flora of Pelican Cays, Belize. Bulletin of the Biological Society of Washington 9:1-149.

Littler DS, Littler MM. 2000. Caribbean reef plants. An identification guide to the reef plants of the Caribbean, Bahamas, Florida and Gulf of Mexico. Offshore Graphics, Washington.

Marinho-Soriano E, Silva IB, Martins EOV, Amaral RF. 2008. Biodiversidade em risco. Ciência Hoje 247:68-70.

Masuda M, Kogame K. 2000. Herposiphonia elongata sp. nov. and H. tenella (Rhodophyta, Ceramiales) from the western Pacific. Cryptogamie, Algologie 21:177-189.

Masuda M, Shimada S. 2002. Taxonomic notes on Herposiphonia vietnamica (Rhodophyta, Ceramiales). Cryptogamie, Algologie 23:13-23.

Masuda M, Shimada S. 2003. A new red alga Herposiphonia japonica (Rhodophyta, Ceramiales) from the northwestern Pacific. Cryptogamie, Algologie 24:195-208.

Masuda M, Tani M, Kurihara A. 2006. Taxonomic notes on species of Herposiphonia (Ceramiales, Rhodophyta) found in Japan. Phycological Research 54: 230-243.

Morrill JF. 1976. Comparative morphology, taxonomy and phylogeny of some parasitic and some dorsiventral Rhodomelaceae. PhD dissertation, University of North Carolina, Chapel Hill.

Nunes JMC. 2005. Rodofíceas marinhas bentônicas do estado da Bahia. Tese de doutorado, Universidade de São Paulo, São Paulo.
N'yeurt ADR, Payri CE. 2010. Marine algal flora of French Polynesia III. Rhodophyta, with additions to the Phaeophyceae and Chlorophyta. Cryptogamie, Algologie 31:3-205.

Oliveira Filho EC. 1969. Algas marinhas do sul do Estado do Espírito Santo (Brasil). I - Ceramiales. Boletim da Faculdade de Filosofia e Ciências, Universidade São Paulo. Série Botânica 26:1-277.

Oliveira Filho EC, Ugadim Y. 1974. Novas referências de algas marinhas bentônicas para a flora brasileira. Boletim de Botânica da Universidade de São Paulo 2:71-91.

Papenfuss GF. 1941. Catalogue and bibliography of Antarctic and Sub-Antarctic marine algae. In Bibliography of the Antarctic Seas 1 (MO Lee, ed.). American Geophysical Union, Washington D.C.

Pereira SMB, Carvalho MFO, Angeiras JA, Pedrosa MEB, Oliveira NMB, Torres J, Gestinari LMS, Concentino AM, Santos MD, Nascimento PRF, Cavalcanti DR. 2002. Algas marinhas bentônicas do estado de Pernambuco. In Diagnóstico da biodiversidade de Pernambuco (M Tabarelli, JMC Silva, orgs.). Secretaria de Ciência, Tecnologia e Meio Ambiente, Editora Massangana, Recife, v.1, 97-124.

Pinheiro-Joventino F, Dantas NP, Maraschin CDH. 1998. Distribuição de algas marinhas no litoral de Fortaleza, Ceará, Brasil. Arquivos Ciências do Mar 31:29-40.

Scagel RF, Gabrielson PW, Garbary DJ, Golden L, Hawkes MW, Lindstrom SC, Oliveira JC, Widdowson TB. 1989. A synopsis of the benthic marine algae of British Columbia, southeast Alaska, Washington and Oregon. Phycological Contributions, University of British Columbia 3:1-532.

Schneider CW, Searles RB. 1991. Seaweeds of southeastern United States: Cape Hatteras to Cape Canaveral. Duke University Press, Durham.

Schneider CW, Searles RB. 1997. Notes on the marine algae of the Bermudas. 2. Some Rhodophyta, including Polysiphonia tongatensis and a discussion of the Herposiphonia secunda/tenella complex. Cryptogamie, Algologie 18:187-210.

Setchell WA. 1926. Tahitian algae and Tahitian Spermatophytes. University of California Publications on Botany 12:61-143.

Silva IB. 2006. Diversidade de macroalgas marinhas bentônicas dos recifes de Maracajaú, Área de Preservação Ambiental dos Recifes de Corais, Rio Grande do Norte, Brasil. Dissertação de mestrado, Universidade Federal do Rio Grande do Norte, Natal.

Silva IB. 2011. Algas marinhas bentônicas dos recifes e ambientes adjacentes de Maracajaú, APA dos Recifes de Corais, RN, Brasil. Tese de doutorado, Instituto de Botânica de São Paulo, São Paulo.

Silva PC, Menez EG, Moe RL. 1987. Catalog of the benthic marine algae of the Philippines. Smithsonian Contributions to the Marine Sciences 27. Smithsonian Institute Press, Washington D.C. 
Stegenga H, Bolton JJ, Anderson RJ. 1997. Seaweeds of the South African west coast. Bolus Herbarium, University of Cape Town, Cape Town.

Széchy MTM, Amado Filho GM, Cassano V, De-Paula JC, Barros-Barreto MB, Marins-Rosa BV, Moreira FM. 2004. Levantamento florístico das macroalgas da baía de Sepetiba e adjacências, RJ: ponto de partida para o Programa GloBallast no Brasil. Acta Botanica Brasilica 19:587-596.

Tessler MG, Goya SC. 2005. Processos costeiros condicionantes do Litoral Brasileiro. Revista do Departamento de Geografia 17:11-23.

Tsuda RT, Abbott IA. 1985. Collecting, handling, preservation, and logistics. In Handbook of phycological methods, v.IV. Ecological field methods: macroalgae (MM Littler, DS Littler, eds.). Cambridge University Press, Cambridge/New York. p.67-86.
Villaça R, Pedrini AG, Pereira SMB, Figueiredo MAO. 2006. Flora marinha bentônica das ilhas oceânicas brasileiras. In Ilhas oceânicas brasileiras da pesquisa ao manejo (RJV Alves, JWA Castro, eds.). Ministério do Meio Aambiente - SBF, Brasília, p.105-146.

Yoneshigue Y. 1985. Taxonomie et ecologie des algues marines dans la region de Cabo Frio, Rio de Janeiro, Bresil. Thèse de Docteur, L'Universite D'Aix-Marseille II, Luminy.

Wynne MJ. 1985. Notes on Herposiphonia (Rhodomelaceae, Rhodophyta) in South Africa, with a description of a new species. Cryptogamie, Algologie 5:167-77.

Wynne MJ. 1998. A checklist of the benthic marine algae of the tropical and subtropical western Atlantic: first revision. Nova Hedwigia Beiheft 116:2239-2281.

Wynne MJ. 2011. A checklist of marine benthic algae of the tropical and subtropical Western Atlantic: third revision. Nova Hedwigia Beiheft 140:1-166. 